\title{
Path Analysis on the Determinants of Adherence to Anti Tuberculosis Drug Treatment in Kaur District, Bengkulu, Indonesia
}

\author{
Surahman Hamidi'), Setyo Sri Raharjo²), Mahendra Wijaya3) \\ 1)Masters Program in Public Health, Universitas Sebelas Maret \\ 2)Faculty of Medicine, Universitas Sebelas Maret \\ 3)Faculty of Social and Political Sciences, Universitas Sebelas Maret
}

\begin{abstract}
Background: Drug treatment compliance was the behavior of patients to take medication and undergo treatment according to the rules determined by professional health personnels. Many factors influenced the compliance with treatment for tuberculosis patients. This study aimed to examine determinants of drug treatment compliance among tuberculosis patients.

Subjects and Method: This was an analytic observational study with a cross-sectional design. The study was conducted at 16 community health centers in Kaur Regency, Bengkulu, Indonesia, from January to February 2019. A sample of 206 study subjects was selected by purposive sampling. The dependent variable was drug treatment adherence. The independent variables were age, gender, education, income, knowledge, role of drug taking supervisor, side effect of drug treatment, distance to health service, drug availability, family support, and tenure. The data were collected by questionnaire and analyzed by path analysis.

Results: Adherence to anti tuberculosis treatment was directly and positively affected by age (b= 2.96; CI $95 \%=1.12$ to $4.79 ; \mathrm{p}=0.002)$, gender $(\mathrm{b}=1.48 ;$ CI $95 \%=0.02$ to $2.95 ; \mathrm{p}=0.047)$, education $(b=2.18$; CI 95\% $=0.24$ to $4.11 ; \mathrm{p}=0.027)$, income $(b=0.85 ; \mathrm{CI} 95 \%=0.76$ to $2.45 ; \mathrm{p}=$ o.031), knowledge $(b=2.27$; CI $95 \%=0.32$ to $4.22 ; p=0.023)$, the role of drug taking supervisor $(\mathrm{b}=3.46$; CI 95\%= 1.57 to $5.36 ; \mathrm{p}<0.001)$, drug availability $(\mathrm{b}=0.04$; $\mathrm{CI} 95 \%=-6.07$ to $6.16 ; \mathrm{p}=$ $0.989)$, and family support $(b=2.97$; CI $95 \%=1.30$ to $4.64 ; \mathrm{p}<0.001)$. It was negatively affected by the side effects of the drug ( $b=-3.07$; CI $95 \%=-4.90$ to $-1.24 ; \mathrm{p}=0.001)$, distance to health service $(b=-1.86 ;$ CI 95\%= -3.61 to $-0.11 ; p=0.037)$, and tenure $(b=-2.16 ;$ CI $95 \%=-3.95$ to $-0.38 ; p=$ o.017). Adherence to anti tuberculosis treatment was indirectly affected by income, knowledge, and role of drug treatment supervisor.

Conclusion: Adherence to anti tuberculosis treatment is directly and positively affected by age, gender, education, income, knowledge, the role of drug taking supervisor, drug availability, and family support. It is negatively affected by the side effects of the drug, distance to health service, and tenure.
\end{abstract}

Keywords : treatment adherence, tuberculosis, determinants, path analysis

\section{Correspondence:}

Surahman Hamidi. Masters Program in Public Health, Universitas Sebelas Maret. Jl. Ir. Sutami 36A, Surakarta 57126, Central Java. Email: surahmanhamidi@student.uns.ac.id. Mobile: 085267456713 .

\section{BACKGROUND}

Tuberculosis (TB) has been around for thousands of years and remains a major global health problem. Tuberculosis causes around 10 million of pain each year and is one of the top ten causes of death in the world (WHO, 2017).

Based on the Global Report Tuberculosis in 2017, globally new tuberculosis cases amounted to 6.3 million people (WHO, 2017). In 2017, new cases of TB in 
Journal of Epidemiology and Public Health (2019), 4(3): 205-214

https://doi.org/10.26911/jepublichealth.2019.04.03.08

Indonesia were 425,089 cases, increasing compared to all tuberculosis cases found in 2016 which amounted to 360,565 cases. (Indonesian Ministry of Health, 2018).

Tuberculosis cases in Bengkulu Province in 2015 showed that 1,809 patients were treated, in 2016, there were 1,838 patients and for 2017 there were 2,388 patients (Bengkulu Health Profile, 2017).

Report on the number of tuberculosis morbidity in Kaur Regency in 2015 was 117 cases treated, in 2016 there were 178 cases and in 2017 there were 226 cases of Tuberculosis found and treated (Kaur District Health Profile, 2017).

Non-compliance with TB treatment is a major problem because it can lead to prolonged treatment, higher costs of treatment and care, an increase in new cases due to high transmission, and a greater risk of drug resistance. All of that would make treatment more complex and more expensive (Osterberg, 2005).

Non-compliance with treatment in tuberculosis patients contributes to the worsening of the overall TB situation, not only increases incidence but also increases the risk of drug resistance (WHO, 2013).

This study aims to determine the determinants that influence treatment compliance with tuberculosis patients.

\section{SUBJECTS AND METHOD}

\section{Study Design}

This was an analytic observation study with a cross sectional design. The study was conducted in Kaur, Bengkulu, South Sumatera, Indonesia, from January 15 to February $15,2019$.

\section{Population and Sample}

Population in this study was tuberculosis patients who underwent the treatment in $\mathbf{1 6}$ Kaur District Health Centers. A sample of 206 TB patients was selected by simple random sampling.

\section{Study Variables}

The dependent variable was drug treatment adherence. The independent variables were age, gender, income, education, knowledge, role of drug taking supervisor, drug side effects, distance from home to health service, drugs availability, family support, and tenure.

\section{Operational Definition of Variables} Treatment compliance was defined as the adherence and accuracy of patients in taking and eating drugs according to the time and amount determined by professional health personnels. Age was defined as the age of the study subject when conducting interviews based on birth date. Gender was defined as the status of the patient based on male or female characteristics. Education was defined as the last education attained by the study subject. Income was defined as the income of study subjects obtained monthly. Knowledge was defined as all that the TB patient knows about the concept of tuberculosis. The role of drug taking advisor was defined as the role of the family or health personnels to remind them of taking medication schedules, seeing swallowing drugs, consulting the disease and taking drugs to health facilities. Drug side effect was defined as uncomfortable feelings felt by study subjects after consuming anti-tuberculosis drugs. Distance was defined as the distance that the study subject travels to a health facility. Drugs availability was defined as the availability of drugs in the appropriate amount and good quality at the time of collection. Family support was defined as all forms of support given by the family to improve compliance with medical treatment for the study subject. Tenure was defined as the work length of the study subject in a day. 


\section{Study Instrument}

The data were collected by questionnaire. The instrument has been tested for content validity, face validity, and reliability.

\section{Data Analysis}

Univariate analysis was used to find out frequency distribution and percentage characteristics of study subjects. Bivariate analysis used Chi-square test. Multivariate analysis was conducted by path analysis.

\section{Research Ethics}

Table 1. Sample Characteristics

\begin{tabular}{|c|c|c|}
\hline Characteristics & $\mathbf{n}$ & $\%$ \\
\hline \multicolumn{3}{|l|}{ Age } \\
\hline $15-64$ years old & 143 & 69.4 \\
\hline$\geq 65$ years old & 63 & 30.6 \\
\hline \multicolumn{3}{|l|}{ Gender } \\
\hline Male & 120 & 58.3 \\
\hline Female & 86 & 41.7 \\
\hline \multicolumn{3}{|l|}{ Education } \\
\hline Low & 123 & 59.7 \\
\hline High & 83 & 40.3 \\
\hline \multicolumn{3}{|l|}{ Income } \\
\hline Low & 129 & 62.6 \\
\hline High & 77 & 37.4 \\
\hline \multicolumn{3}{|l|}{ Knowledge } \\
\hline Poor & 105 & 51 \\
\hline Good & 101 & 49 \\
\hline \multicolumn{3}{|c|}{ The role of drug taking supervisor } \\
\hline Poor & 117 & 56.8 \\
\hline Good & 89 & 43.2 \\
\hline \multicolumn{3}{|l|}{ Drug side effects } \\
\hline Low & 104 & 50.5 \\
\hline Severe & 102 & 49.5 \\
\hline \multicolumn{3}{|l|}{ Distance of home } \\
\hline Near & 134 & 65 \\
\hline Far & 72 & 35 \\
\hline \multicolumn{3}{|l|}{ Drug availability } \\
\hline Poor & 34 & 16.5 \\
\hline Enough & 172 & 83.5 \\
\hline \multicolumn{3}{|l|}{ Family support } \\
\hline Poor & 100 & 48.5 \\
\hline Good & 106 & 51.5 \\
\hline \multicolumn{3}{|l|}{ Tenure } \\
\hline$<7$ hours & 86 & 41.7 \\
\hline$\geq 7$ hours & 120 & 58.3 \\
\hline \multicolumn{3}{|c|}{ Drug treatment adherence } \\
\hline Not adhere & 98 & 47.6 \\
\hline Adhere & 108 & 52.4 \\
\hline
\end{tabular}

Research ethics include informed consent, anonymity, confidentiality, and ethical clearance. Research ethics were obtained from Faculty of Medicine, Universitas Sebelas Maret, Surakarta, Central Java, with ID number: 431/UN27.6/KEPK/2019.

\section{RESULTS}

\section{Sample Characteristics}

Sample characteristics were described in Table 1. 
Journal of Epidemiology and Public Health (2019), 4(3): 205-214

https://doi.org/10.26911/jepublichealth.2019.04.03.08

\section{Bivariate Analysis}

Bivariate analysis (Table 2) examined the effects of age, gender, education, income, knowledge, the role of drug taking supervisor, drug side effects, family support, and tenure on drug treatment adherence.

Table 2. Bivariate analysis on the determinants of drug treatment adherence among Tuberculosis patients

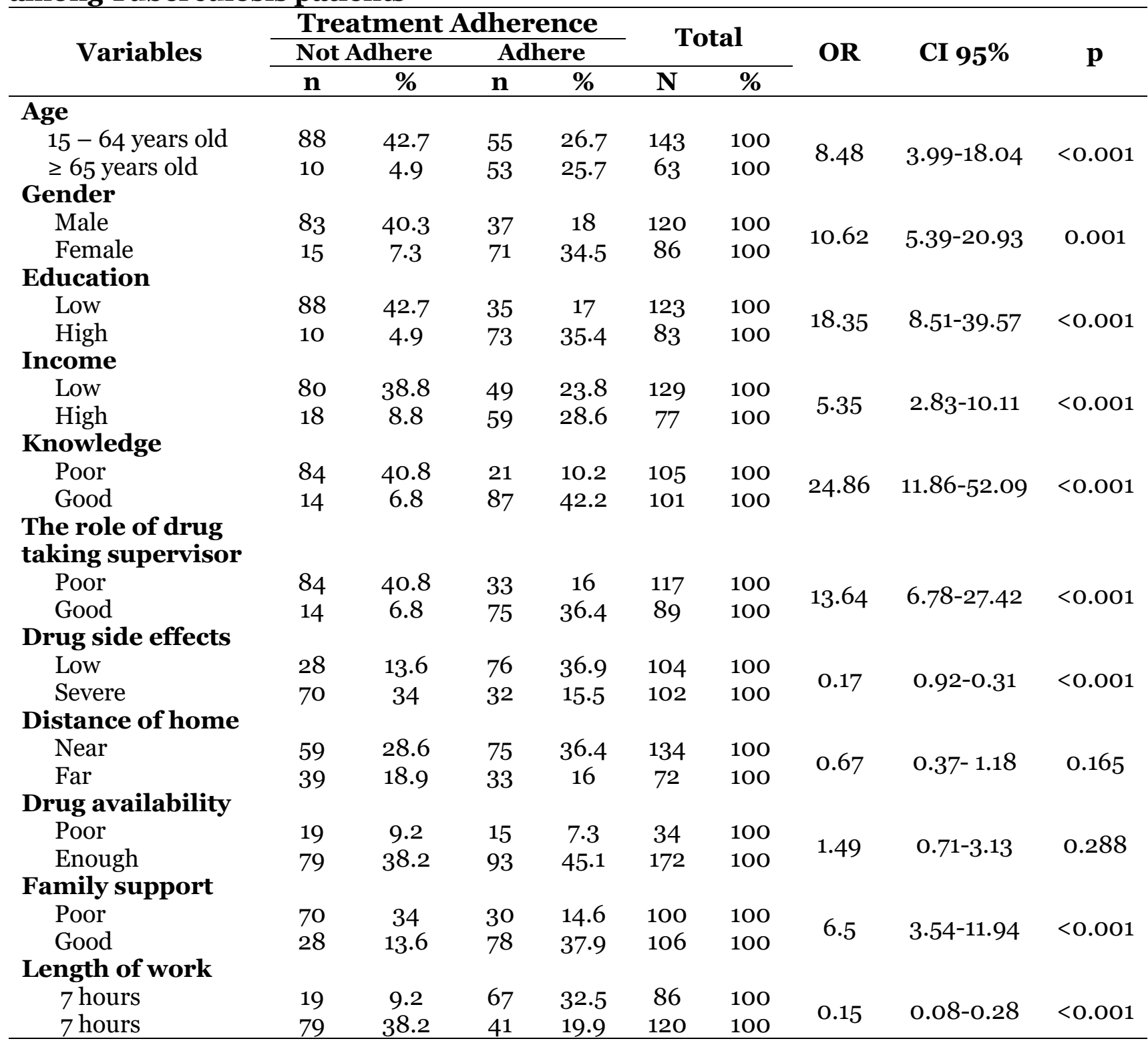

\section{Path Analysis}

Path analysis of the data employed model that was run on STATA 13 program. The The model in this study was in accordance with the sample data shown by the saturation model and also the regression coefficient was more than zero and it was statistically significant, it did not need to be respecification.
Table 3 showed that TB treatment adherence was directly and positively effected by age <65 years old and it was statistically significant $(b=2.95 ; 95 \% \mathrm{CI}=$ 1.12 to $4.79 ; \mathrm{p}=0.002$ ).

TB treatment adherence was directly and positively effected by female gender and it was statistically significant $(b=1.48$; $95 \% \mathrm{CI}=0.02$ to $2.95, \mathrm{p}=0.047$ ). 


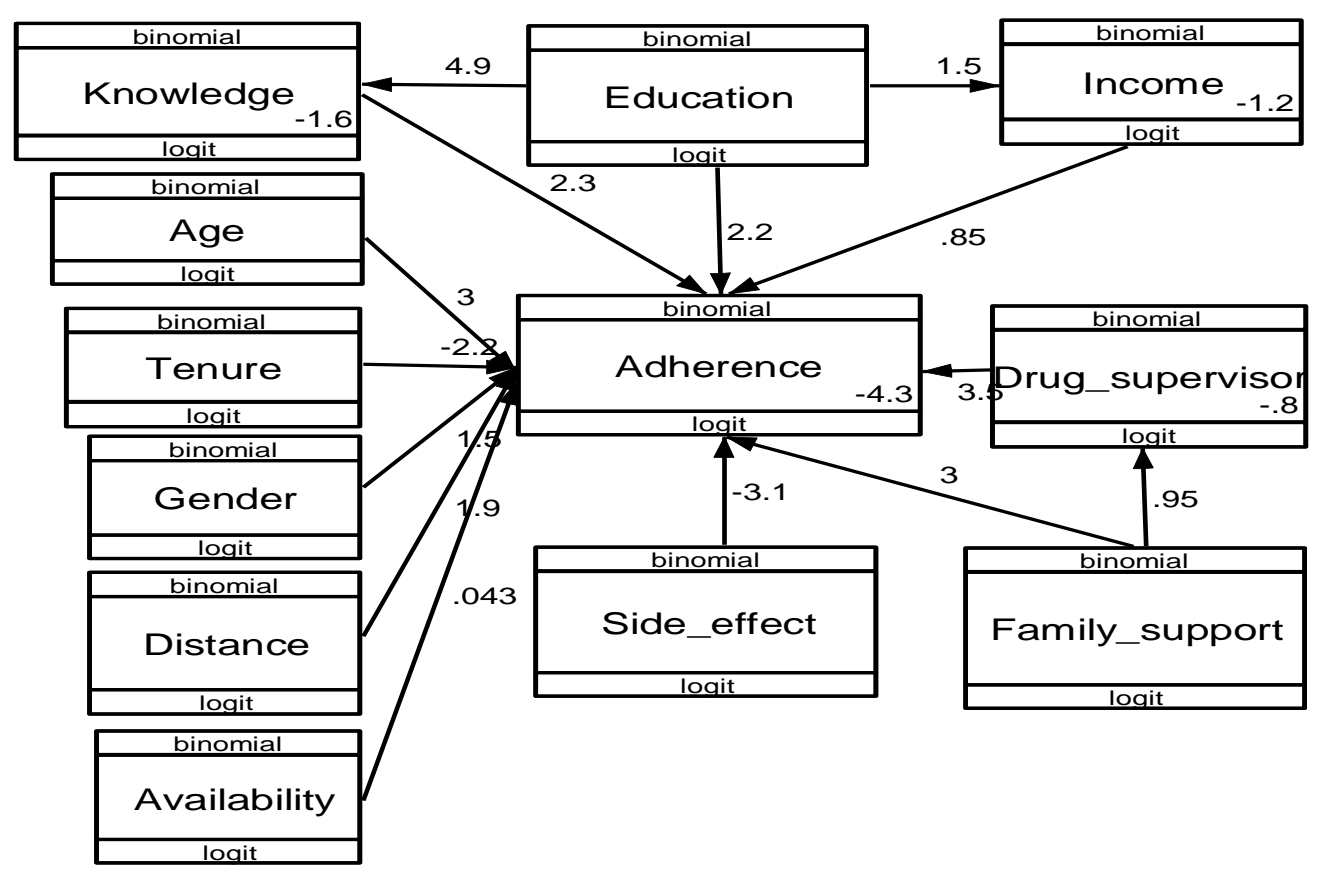

Figure 1. Path analysis model with estimates

Table 3. Path analysis on the determinants of TB treatment adherence

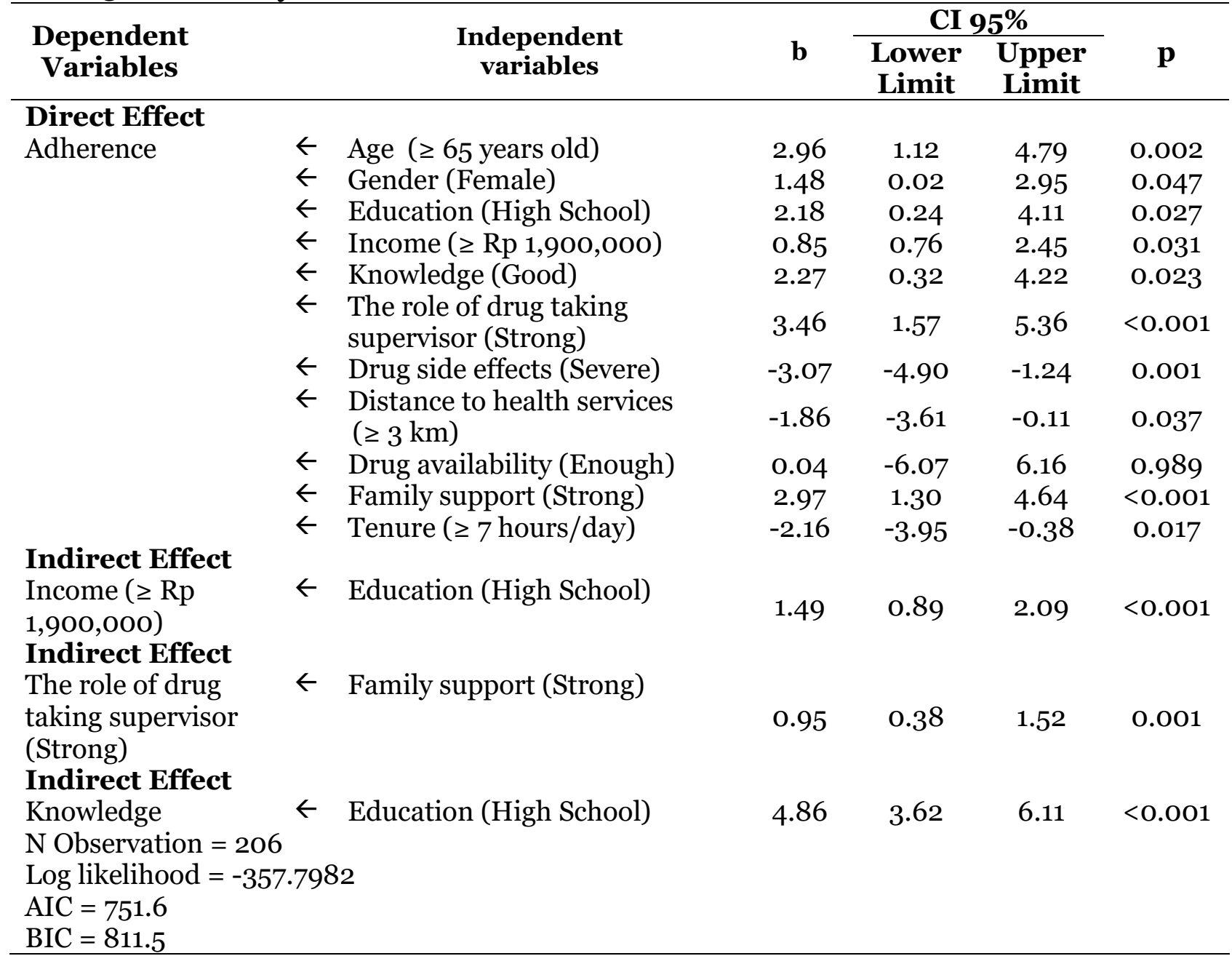


Drug treatment adherence was directly and positively affected by high education level and it was statistically significant $(\mathrm{b}=$ $2.18 ; 95 \% \mathrm{CI}=0.24$ to $4.11 ; \mathrm{p}=0.027$ )

Drug treatment adherence was directly and positively affected by high income and it was statistically significant $(b=0.85$; $95 \% \mathrm{CI}=0.76$ to $2.45 ; \mathrm{p}=0.031$ )

Drug treatment adherence was directly and positively affected by high knowledge and it was statistically significant $(\mathrm{b}=2.27$; $95 \% \mathrm{CI}=0.32$ to $4.22, \mathrm{p}=0.023$ ).

Drug treatment adherence was directly and positively affected by strong role of drug taking supervisor and it was statistically significant $(b=3.46 ; 95 \% \mathrm{CI}=1.57$ to 5.36 ; $\mathrm{p}<0.001$ ).

Drug treatment adherence was directly and positively affected by family support and it was statistically significant $(b=2.97$; 95\% $\mathrm{CI}=1.30$ to $4.64 ; \mathrm{p}<0.001$ ).

Drug treatment adherence was directly and negatively affected by tenure $\geq 7$ hours/day and it was statistically significant $(\mathrm{b}=-1.86 ; 95 \% \mathrm{CI}=-3.61$ to $-0.11 ; \mathrm{p}=$ o.037).

Drug treatment adherence was directly and positively affected by drug availability but it was statistically non-significant $(b=0.04 ; 95 \% \mathrm{CI}=-6.07$ to $6.16 ; \mathrm{p}=0.989$ ).

Drug treatment adherence was directly and negatively affected by drug side effect and it was statistically significant $(b=$ $-3.07 ; 95 \% \mathrm{CI}=-4.90$ to $-1.24 ; \mathrm{p}=0.001$ ).

Drug treatment adherence was directly and negatively affected by distance to health services $\geq 3 \mathrm{~km}$ and it was statistically significant $(b=-1.86 ; 95 \% \mathrm{CI}=-3.16$ to $0.11 ; \mathrm{p}=0.037$ ).

Drug treatment adherence was indirectly affected by education through knowledge. Knowledge increased with education ( $b=4.86 ; 95 \% \mathrm{CI}=3.62$ to $6.11 ; \mathrm{p}<0.001$ ).

Drug treatment adherence was indirectly affected by income through educa- tion. Income increased with high education and it was statistically significant $(b=1.49$; $95 \% \mathrm{CI}=0.89$ to 2.09 ; $\mathrm{p}<0.001$ ).

Drug treatment adherence was indirectly affected by education family support through the role of drug taking supervisor. Drug taking supervisor increased with family support and it was statistically significant $(\mathrm{b}=0.95 ; 95 \% \mathrm{CI}=0.38$ to $1.52 ; \mathrm{p}=$ 0.001).

\section{DISCUSSION}

\section{The effect of age on drug treatment adherence of tuberculosis patients}

The results of this study indicated that age had a direct and positive effect on tuberculosis treatment adherence. Young productive age would affect the pattern of daily activities of tuberculosis patients. A productive age full of activities would have an impact on the compliance of treatment for tuberculosis patients.

The result of this study was in accordance with Ariani (2015) which stated that the age of TB patients had strong relationship with anti TB treatment adherence $(r=0.76)$. This study was also in accordance with Zabert et al. (2013) in Ariani (2015) which showed that the characteristics of patients in which there were age were influential factors with treatment adherence for tuberculosis patients

\section{The effect of gender on drug treat- ment adherence of tuberculosis patients}

The results of this study showed that there was a direct and positive effect between gender and treatment adherence of tuberculosis patient and it was statistically significant. In male, the adherence was higher due to social interaction, because of smoking tobacco and drinking alcohol so that younger people were exposed to the causative agent of tuberculosis. 
This study was in accordance with the research conducted by Lachaine et al., in 2013 in Ariani (2015) which found that in cases of chronic diseases, male aged $>60$ years old had higher adherence compared to women aged $>60$ years old.

\section{The effect of education on drug treatment adherence among TB patients}

The results of this study showed that there was a direct and positive effect between education and treatment adherence of tuberculosis patient and it was statistically significant.

The result of this study was in line with Vera (2017), which stated that education $\geq$ Senior highs school increased TB medication adherence through perceived benefit.

This study was in accordance with Kondoy (2014), which showed that there was a relationship between education and the level of treatment adherence among tuberculosis patients.

\section{The effect of income on drug treat- ment adherence among TB patients}

The results of this study showed that there was a direct and positive effect between income and treatment adherence of tuberculosis patients and it was statistically significant.

With a high income, people would be able to provide health cost and also able to create a healthy environment and nutrious foods (Ariyani, 2016).

This study was in accordance with a study by Boru et al. (2016), which showed that there was an effect of family income on treatment adherence of tuberculosis patient. This study was also in accordance with $\mathrm{Xu}$ et al. (2010), which stated that financial burden among TB patients was one of the main problems of non-adherence treatment.

\section{The effect of knowledge on drug treatment adherence among TB patients}

The results of this study showed that there was a direct and positive effect between knowledge and treatment adherence of tuberculosis patient and it was statistically significant.

A study by Puspitasari (2016) in Cilacap, Central Java, reported that high knowledge increased positive attitude and strong intention of TB patients to adhere for drug treatment.

This study was in accordance with Adene et al. (2017), which showed that there was a relationship between knowledge and control compliance of tuberculosis patients in Ethiopian prisons.

This study was also in accordance with Wulandari (2015) which showed that knowledge about TB was a risk factor for non-compliance in advanced pulmonary $\mathrm{TB}$ patients.

\section{The effect of the role of drug taking supervisor on treatment adhe- rence of tuberculosis patients}

The results of this study showed that there was a direct and positive effect between the role of drug taking supervisor and treatment adherence of tuberculosis patient and it was statistically significant.

A study by Alfiyani (2017) in Surakarta, Central Java, reported that the role of drug taking supervisor directly increased medical treatment adherence among TB patients.

Drug taking advisor was a person who accompanies and supervises in carrying out treatment. This study was in accordance with Wulandari (2015), which stated that weak drug taking supervisor support was increased the risk of irregular drug taking adherence by 11.3 times. 
Journal of Epidemiology and Public Health (2019), 4(3): 205-214

https://doi.org/10.26911/jepublichealth.2019.04.03.08

\section{The effect of drug side effects on drug treatment adherence among TB patients}

The results of this study showed that there was a direct and negative effect between drug side effectsand treatment adherence of tuberculosis patient and it was statistically significant.

Alfiyani (2017) reported that drug side effect directly decreased drug taking adherence among TB patients in Surakarta, Central Java.

This study was in accordance with study by Wulandari (2015), which stated that pulmonary tuberculosis patients with severe side effects resulted in a risk of noncompliance by 6.1 times.

\section{The effect of distance from home to health services on drug treat- ment adherence among TB patients}

The results of this study showed that there was a direct and positive effect between distance to services and treatment adherence of tuberculosis patient and it was statistically significant. The results of this study showed that tuberculosis patients with close distance to health services directly increased the compliance with treatment for tuberculosis patients.

This study was in accordance with Wulandari (2015), which showed that distance was a risk factor for the occurrence of non-compliance in patients with advanced pulmonary tuberculosis while long-term tuberculosis sufferers have a risk of noncompliance by 7.1 times greater than patients with close distance.

\section{The effect of drug availability on drug treatment adherence among TB patients}

The results of this study indicated that there was a direct effect between the drug availability with drug treatment adherence among TB patients but it was statistically non-significant.

In this study, there was no significant availability of drugs for treatment compliance with tuberculosis patients because almost all health service facilities were available for drugs both in quantity and quality in accordance with the standards of tuberculosis prevention programs.

\section{The effect of family support on drug treatment adherence among TB patients}

The results of this study indicated that there was a direct and positive effect of family support on treatment adherence of tuberculosis patient and it was statistically significant. The results of this study showed that tuberculosis patients with strong family support directly increased drug treatment adherence by 2.97 units.

A study by kurniawan (2010), stated that family support made the tendency of patients to be more obedient in treating tuberculosis. This study was in line with Gunawan (2017), which stated that the factor of family support was the most influential factor in treatment compliance for tuberculosis patients.

\section{The effect of tenure on drug treat- ment adherence among TB patients}

The result of this study showed that there was a direct and negative effect of tenure and drug treatment adherence of TB patient and it was statistically significant. This study showed that tuberculosis patients with long tenure $\geq 7$ hours/day had a direct effect of decreasing 2.16 units of adherence to treatment for tuberculosis patients.

High activity or working hours sometimes made people to be complacent and negligent in taking care of themselves, including controlling or treating their illness (Ministry of Health, 2014). 
In this study, the majority of the sample (58.3\%) worked $\geq 7$ hours per day and the majority was farmers and fishermen who worked daily so that treatment compliance was low.

\section{REFERENCES}

$\overline{\text { Adane K, Spight M, Johanna L, Noortje D, }}$ Abera FA, Dinant GJ (2017). Tuberkulosis knowledge, attitudes, and practise among Northren Prisoners: Implication For TB Control Efforts. Plos One. 12(3): e0174692. http://doi.org/10.1371/journal

Ariani NW, Rattu AJM, Ratag B (2015). Faktor-faktor yang berhubungan dengan keteraturan minum obat penderita tuberkulosis paru di wilayah kerja Puskesmas Madayang, Kabupaten Dolaang Mangandow Timur. JIKMU. 5(1). www.ejournal.unsrat.ac.id.

Ariyani H (2016). Hubungan tingkat pengetahuan dengan kepatuhan pada pengobatan penderita tuberkulosis paru di puskesmas Pekauman Kota Banjarmasin. Jurnal Pharma Science, 03(02).

Boru CG, Shimels T, Bilal AI (2017). Factor contributing to non adherence with treatment among tb patients in Sodo Woreda, Soutern Ethiophia: A Qualitative Study. Journal Of Infection and Public Health: 10: 527 533. http://elsevier.com/docate.ijrph.

Dinkes Kabupaten Kaur (2018). Profil kesehatan kabupaten Kaur Tahun 2017. Bintuhan: Dinas Kesehatan Kabupaten Kaur.

Dinkes Provinsi Bengkulu (2018). Profil kesehatan provinsi Bengkulu Kaur Tahun 2017. Bengkulu: Dinas Kesehatan Provinsi Bengkulu.

Friedmen (1998). Keperawatan Keluarga. Jakrta: EGC
Green LW, Kreuter MW (2000). Health promotion planning; An educational and enviromental approach, second edition. London: Mayfield Publishing Company.

Gunawan AR, Simbolon RL, Fauzia D (2017). Faktor-faktor yang mempengaruhi tingkat kepatuhan pasien terhadap pengobatan tuberkulosis Paru di Lima Puskesmas Se-Kota Pekanbaru. JOM FK: 4 (2).

Kemenkes RI (2014). Pedoman Nasional Pengendalian Tuberkulosis. Jakarta: Kementerian Kesehatan RI.

(2018). Profil Kesehatan Indonesia 2017. Jakarta: Kementerian Kesehatan RI.

Kisambu J, Nuwaha F, Sekandi JN (2014). Adherence to treatment and supervision for tuberkulosis in a DOTS programme among postoralists in Uganda. International Journal Tuberkulosis Disease 18(7): 799-853 http://dx.doi.org/10.538-/ijtld.13.0753

Alfiyani L, Demartoto A, Murti B (2017). Biopsychosocial determinants of multi drug resistant tuberculosis in Surakarta, 2(3): 255-266. http://doi.org/10.26911/jepublichealth.2017.02. 03.07

Kondoy, Priska PH (2014). Faktor-faktor yang berhubungan dengan kepatuhan berobat pasien tuberkulosis paru di Lima Puskesmas di Kota Manado. Jurnal Kedokteran Komunitas dan Topika: 15 (1)

Mokennen HS, Azagew AW (2018). Nonadherence to anti-tuberkulosis treatment, reason and associated factors among TB patients attending at Gondar Town Health Centers, Northwest Ethiopia. BMC Research Notes 11: 691. https://-doi.org/10.1186/s131040183789-4

Murti B (2018). Prinsip dan Metode Riset 
Journal of Epidemiology and Public Health (2019), 4(3): 205-214

https://doi.org/10.26911/jepublichealth.2019.04.03.08

Epidemiologi Edisi ke Empat. Surakarta: Program Pasca Sarjana, Universitas Sebelas Maret.

Notoatmodjo S (2003). Pendidikan dan perilaku kesehatan. Rineka Cipta. Jakarta.

Nursalam (2008). Konsep dan penerapan metodologi penelitian keperawatan. Jakarta: Info medika

Osterberg L, Blaschke T (2005). Adherence to Medication. N. Engl. J. Med, 353, 487-497.

Puspitasari L, Murti B, Demartoto, A (2016). Social support on the adherence to treatment of tuberculosis in Cilacap, Indonesia. Journal of Epidemiology and Public Health, 1(1): 5865. http://doi.org/-jepublichealth.2016.01.01.07

Vera, Rahardjo SS, Murti B (2017). Health belief model and PRECEDE PROCEED on the risk factors of multidrug resistant tuberculosis in Surakarta, Central Java, 2(3): 241-254. http://doi.org/10.26911/jepubli-chealth.2017.02.03.06
WHO (2013). Adherence To Long - Term Therapies: Evidence For Action. Geneva. (2017). Global Tuberkulosis Report 2016. Geneva. (2018). Global Tuberkulosis Report 2017. Geneva: World Health Organization

Wulandari DH (2015). Analisis faktorfaktor yang berhubungan dengan kepatuhan pasien tuberkulosis dari tahap untuk minum obat di RS Rumah Sehat Terpadu Tahun 2015. Jurnal Administrasi Rumah Sakit. 2(1): $17-28$

Xu L, Gai R, Wang X, Liu Z, Cheng J, Zhou C, Liu J, Zhang H, Li H, Tang W (2010). Socio-economic factors affecting the success of tuberkulosis treatment in six countries of Shandong Province, China. International Journal Tuberkulosis Lung Diseases 2010 (14): 440-446. 